\title{
Urban Black Violence: The Effect of Male Joblessness and Family Disruption
}

\section{Citation}

Sampson, Robert J. 1987. Urban black violence: the effect of male joblessness and family disruption. American Journal of Sociology 93, no. 2: 348-383.

\section{Published Version}

http://dx.doi.org/10.1086/228748

\section{Permanent link}

http://nrs.harvard.edu/urn-3:HUL.InstRepos:3226953

\section{Terms of Use}

This article was downloaded from Harvard University's DASH repository, and is made available under the terms and conditions applicable to Other Posted Material, as set forth at http:// nrs.harvard.edu/urn-3:HUL.InstRepos:dash.current.terms-of-use\#LAA

\section{Share Your Story}

The Harvard community has made this article openly available.

Please share how this access benefits you. Submit a story.

Accessibility 


\title{
Urban Black Violence: The Effect of Male Joblessness and Family Disruption ${ }^{1}$
}

\author{
Robert J. Sampson \\ University of Illinois at Urbana-Champaign
}

This paper examines the relationships among unemployment, crime, and family disruption in the black "underclass." The main hypothesis tested is that the effect of black adult male joblessness on black crime is mediated largely through its effects on family disruption. The study examines race-specific rates of robbery and homicide by juveniles and adults in over 150 U.S. cities in 1980 . The results show that the scarcity of employed black men increases the prevalence of families headed by females in black communities. In turn, black family disruption substantially increases the rates of black murder and robbery, especially by juveniles. These effects are independent of income, region, race and age composition, density, city size, and welfare benefits and are similar to the effects of white family disruption on white violence. The paper concludes that there is nothing inherent in black culture that is conducive to crime. Rather, persistently high rates of black crime appear to stem from the structural linkages among unemployment, economic deprivation, and family disruption in urban black communities.

Race is one of the strongest predictors of major social dislocations in American cities. Black communities are characterized by disproportionately high rates of drug addiction, welfare dependence, out-of-wedlock births, teenage pregnancy, and families headed by females (Wilson 1981, 1984; Wilson and Aponte 1985; Hogan and Kitagawa 1985). Black communities are also plagued by an unusually high level of violent crimeblack males in the United States face a startling one-in-21 lifetime chance of being murdered (Bureau of Justice Statistics 1985a, p. 8). Further, blacks are disproportionately represented as offenders: they account for

\footnotetext{
1 This paper was supported in part by a grant funded by the National Institute of Justice (84-IJ-CX-0067). Points of view expressed herein are those of the author and do not necessarily represent the official position of the Justice Department. I would like to thank Lowell Hargens, Nancy Sampson, and two anonymous AJS reviewers for extremely helpful comments on an earlier version of this paper. Requests for reprints should be sent to Robert J. Sampson, Department of Sociology, University of Illinois, Urbana, Illinois 61801 .
}

(C) 1987 by The University of Chicago. All rights reserved. 0002-9602/88/9302-0004\$01.50 
approximately $61 \%$ of robbery arrests and $55 \%$ of homicide arrests, while representing only $11 \%$ of the general population (U.S. Department of Justice 1981). ${ }^{2}$ The extremely high level of black offending and black victimization has led Wilson (1984, p. 79) to conclude that "perhaps the most dramatic indicator of the extent to which social pathology has afflicted urban blacks is crime, especially violent crime."

Despite the seriousness of the problem, theoretical and empirical analyses of urban black dislocations are weak, especially on the extent to which criminal violence is linked to patterns of family structure. A major reason is the lack of racially disaggregated empirical research. As noted by Wilson (1984; see also Wilson and Aponte 1985), until the early 1980s, sociologists tended to shy away from race as a topic of serious scholarly attention. Wilson (1984, p. 76) argues that the reluctance to study behavior that could be construed as unflattering or stigmatizing to particular racial minorities stems from the sharp criticisms aimed at scholars such as Rainwater (1966) and Moynihan (1965) and the resulting effort by liberal social scientists to protect their work from the charge of racism or of "blaming the victim."

Second, the theoretical attention that has been focused on these issues has tended to neglect the role of embedded structural factors such as black male joblessness. For example, the literature on black family disruption has concentrated on liberal welfare policies and on the perceived failure of the Great Society (see Aponte, Neckerman, and Wilson 1985, p. 5; Wilson and Neckerman 1985, p. 34), while the criminological literature on black violence has been dominated by a focus on individual-level factors (e.g., IQ) and subcultural explanations (for recent reviews, see Wilson and Herrnstein 1985, pp. 466-84; Messner 1983). In particular, the prevailing viewpoint on black violence is the subculture-of-violence thesis (Wolfgang and Ferracuti 1967; Curtis 1975). Analogous to the culture-of-poverty thesis, this perspective asserts that high black crime rates and the strong positive effect of percentage black on the aggregate homicide rate (see Messner 1983) reflect a cultural system unique to the black experience. The subculture-of-violence thesis thus maintains that violent criminal acts such as homicide and assault are expressions of a subcultural value system that condones and legitimates violence (Curtis 1975).

The lack of structural viewpoints and systematic empirical analysis of black violence is further exacerbated by data limitations. Data on serious predatory crimes committed by blacks are commonly presented in the

${ }^{2}$ The disproportion of blacks arrested cannot be explained away simply by charges of racial discrimination in criminal justice processing (see Hindelang 1978). This issue is discussed in more detail below. 
form of national estimates (e.g., Hindelang 1978; U.S. Department of Justice 1981), as the Uniform Crime Report (UCR) system does not release race-specific counts by city or other macrosocial units. Self-report data are even more limited, as they contain information mostly on minor juvenile offenses and are collected either in one city (e.g., Hindelang, Hirschi, and Weis 1981) or for the nation as a whole (Elliott and Ageton 1980). And, although there have been numerous studies using aggregate crime rates (i.e., reported offenses per population) to study the effects of racial composition, poverty, and inequality (see, e.g., Blau and Blau 1982; Messner 1982; Byrne and Sampson 1986), the race of offender is not identified in offense data. Race-specific offending rates, in conjunction with the data in which structural conditions of theoretical importance are allowed to vary, are practically nonexistent.

The limitations of past research have thus had serious consequences not only for theoretical development but for social policy and public opinion as well. As Wilson (1984, p. 90) has noted, because there has been so little recent systematic research and so few cogent explanations of black social dislocations, racial stereotypes of life and behavior in the urban ghetto have not been sufficiently rebutted. Relatedly, the effort by liberal social scientists to ignore high rates of black crime appears to have backfired: current crime-control policies account for an ever-increasing rate of black incarceration and execution (Blumstein 1982; Bureau of Justice Statistics 1985b, 1985c). Indeed, at current incarceration rates, a black male born in the United States today is estimated to have a one-infive chance in his lifetime of serving a sentence in an adult state prison; further, in the period 1978-82 alone, the percentage of the adult black males in the U.S. population incarcerated in prison increased $23 \%$ (Bureau of Justice Statistics 1985c, p. 5).

In the present study, I address the methodological and theoretical limitations of previous research by examining the relationship between urban black violence and family dissolution in U.S. cities. In contrast to individualistic and cultural explanations, this paper examines a macrolevel framework derived from a linkage of demographic and structural explanations of the determinants of black family dissolution (Wilson 1978; Wilson and Neckerman 1985) with criminological perspectives on the consequences of family disruption for community crime rates (Sampson 1986a, 1986b; Felson 1986; Felson and Cohen 1980). Hypotheses are tested with the use of recently developed methods to disaggregate homicide and robbery offending rates demographically by race and age in large U.S. cities. These cities vary tremendously in family structure, economic deprivation, and male joblessness and hence offer a unique opportunity to test competing explanations of the determinants of black urban violence. 


\section{THEORETICAL FRAMEWORK}

That the family structure of blacks differs dramatically from that of whites is beyond question-42\% of black families with children are headed by females, compared with $11 \%$ of white families (Wilson and Neckerman 1985 , p. 50). Further, the rate of black families with female heads has increased approximately 100\% from 1960 to 1980 (Wilson and Aponte 1985, p. 240). Beginning with his seminal work on race relations in the United States (Wilson 1978), Wilson and colleagues (Wilson and Neckerman 1985; Wilson 1984; Wilson and Aponte 1985) have argued that the increase in black families headed by females and extramarital births may be tied to the increasing difficulty of finding a marriage partner with stable employment (Wilson 1978, pp. 132-34; Wilson and Neckerman 1985, pp. 25-30; see also Ross and Sawhill 1975, pp. 161-62; Bishop 1980). That is, independent of cultural values regarding out-ofwedlock births (e.g., an inherent matriarchal tendency or a culture of poverty among blacks) and increases in funds available from welfare (see Murray 1984), Wilson's thesis is that an important structural source of black family disruption is black male joblessness.

Computing a "male marriage pool index" (MMPI) comprising employed men per 100 women of the same age and race, Wilson and Neckerman (1985, pp. 61-68) note long-term declines in the pool of economically stable black men and levels much lower for blacks than for whites. For example, in 1980, there were approximately 85 employed white males per 100 white women 25-34 for the nation as a whole, compared with only about 55 employed black males per 100 black women. Wilson and Neckerman $(1985$, p. 27$)$ thus argue that the weight of the evidence "suggests that the increasing rate of joblessness among black men merits serious consideration as a major underlying factor in the rise of black single mothers and female-headed households." Wilson's thesis is buttressed by a long line of demographic and ethnographic research linking unemployment to marital instability (see, e.g., Bishop 1980, pp. 302-8; Liebow 1967).

Although the evidence is not quite as consistent as that on unemployment, several studies have also shown that income and occupational status are inversely related to marital instability. For instance, divorce and separation rates tend to be higher among lower-income families (Cutright 1971), and other evidence suggests that the higher the husband's earnings, the less likely black couples are to divorce (Wilson and Neckerman 1985, p. 27). In addition, Ross and Sawhill (1975, p. 214) found that the rates of black families with female heads in 41 cities were inversely related to median income of intact families, net of control variables.

In brief, an accumulating body of evidence suggests that the labor- 
market marginality of black males and accompanying economic deprivation have had profound negative implications for the black community, particularly for black women with children (Liebow 1967; Rainwater 1966, 1970, 1985; Wilson and Neckerman 1985; Wilson 1984). From this viewpoint, the major structural determinant of black family disruption is black male joblessness. And, in contrast to some versions of the popular "feminization of poverty" argument, black family disruption is also seen largely as a consequence rather than as a cause of persistent poverty in the black community. ${ }^{3}$

\section{Family Structure and Crime}

There are at least three reasons to expect that the family disruption hypothesized to stem from male joblessness in urban black communities may in turn have important implications for explaining crime rates. The first derives from the traditional criminological concern with whether broken homes cause juvenile delinquency at the individual level. Although empirical evidence on this issue is inconsistent (see, e.g., Wilkinson 1980; Ross and Sawhill 1975, pp. 133-39), recent longitudinal research on black youths in urban areas reveals a negative effect of family stability on juvenile delinquency (Ensminger, Kellam, and Rubin 1983). Also, the marital conflict and unhappiness often fueling family dissolution are well-established predictors of delinquency (Loeber and StouthamerLoeber 1986). The ecological fallacy notwithstanding, then, urban black communities with pronounced family disruption may contribute to disproportionately high rates of juvenile delinquency.

Second, marital and family disruption may decrease formal social controls at the community level (Sampson 1986a, 1986b). For example, Bloom (1966) found that areas with high family disruption had low rates of participation in community politics, recreation (e.g., the YMCA), and educational activities (e.g., library membership). Similarly, Kellam et al. (1982) found that black single-parent mothers in a Chicago ghetto participated less often in social and political organizations than did mothers in

\footnotetext{
${ }^{3}$ Bane found that, among blacks, poor single-person households and those headed by females are much more likely to be formed from households that were already poor $(1985$, p. 39) and that the vast majority of poor, black, single-parent mothers could not have avoided poverty had families stayed together. Bane refers to this as a "reshuffling" of poverty rather than an "event-driven" poverty, the latter of which is more common among whites. In other words, among blacks, poor two-parent families tend to break apart into poor single-person households and ones headed by females, while better-off families remain together (Bane 1985, p. 19). This is consistent with the present theoretical framework, which argues that economic marginality and deprivation have fostered a community in which it is difficult for blacks to maintain twoparent families (see also Rainwater 1985, p. 2).
} 
two-parent families. The evidence thus suggests that communities with pronounced family disruption may experience a weakening of formal and voluntary organizations, many of which play crucial roles in linking local youths to wider social institutions and in fostering desired principles and values (Janowitz 1975, pp. 82, 88; Kornhauser 1978, pp. 81-82).

A third potential consequence of family disruption for communities is attenuated informal controls (Sampson 1986b, pp. 278-80; Felson and Cohen 1980; Felson 1986). Examples of informal social control include neighbors' taking note of or questioning strangers, watching over one another's property, assuming responsibility for supervision of general youth activities, and intervening in local disturbances (see Greenberg, Rohe, and Williams 1985; Skogan 1986). Two-parent households provide increased supervision and guardianship not only for their own children and household property (Cohen and Felson 1979) but also for public activities in the community. For example, two-parent families are probably effective not so much because they are able to intervene in actual criminal acts but because they are better able to control those peer group activities (e.g., "hanging out," vandalism, truancy) that set the context for more serious crime, especially gang delinquency (see Cartwright and Howard 1966). Indeed, a central fact in criminological research is that most delinquents have delinquent friends and commit delinquent acts in groups (Zimring 1981). Consequently, as Felson (1986, p. 124) argues, the awareness and supervision of peer-group and gang activity is not simply dependent on one child's family but on a network of control: "The singleparent household gives the community only one parent to know and hence reduces the potential linkages which can be invoked for informal social control."

\section{RESEARCH STRATEGY AND HYPOTHESES}

A synthesis of the above review suggests that there are large differences among communities in family structure and that these differences may have important consequences for the social control of crime and delinquency. ${ }^{4}$ Further, the evidence also indicates that family disruption is much more acute in black communities than in white communities, as are persistent poverty and male joblessness. In fact, the data I present below show that the racial differences are so strong that the worst urban contexts in which whites reside with respect to poverty and family disruption

${ }^{4}$ This view does not deny that family and marital breakup may have positive consequences for particular individuals (e.g., ending a bad marriage) or that white and black families headed by females may possess adaptive and admirable qualities (e.g., Stack 1974). Rather, the focus is macrosociological-the structural implications of family dissolution for explaining variation in crime rates. 
are considerably better off than the mean levels for black communities. Thus, regardless of whether a black juvenile is reared in an intact or broken home, he or she will not grow up in a community context similar to that of whites with regard to family structure and poverty.

From a sociological perspective, these structural differences among communities are theoretically important but have not been systematically explored since most previous research has concentrated either on individual-level analysis or on aggregate analysis that masks and confounds racial differences in crime, family structure, and economic deprivation. To address the problem, the solution I propose here is to conduct groupspecific (i.e., racially disaggregated) analyses across macrosocial units that vary along the theoretical dimensions of interest.

The major hypothesis is that variations in rates of black family disruption in urban areas are positively related to rates of black criminal offending, independent of those factors (e.g., poverty) associated with families headed by females and frequently hypothesized as providing motivation for crime. To the extent that the disruption of families is linked primarily to the social control of juveniles and their peer groups, the effect of family structure on crime should be strongest for juveniles. But since family disruption is hypothesized to increase generally the opportunities for crime (see Felson and Cohen 1980), and since disproportionate numbers of those who are divorced or separated in a population may be indicative of much instability, disorientation, and conflict in adult personal relations (Blau and Blau 1982, p. 124), community family disruption is expected to be significantly related to adult criminality as well.

The specific hypothesis by Wilson and Neckerman (1985) is that, independent of welfare policies, regional differences, and possible cultural factors measured by the size of the black population (see Curtis 1975), black male employment (i.e., the black male marriage pool) will have a direct inverse effect on black family disruption. This hypothesis is also consistent with the ethnographic research of Liebow (1967) and Rainwater (1970), who argue that the family dissolution that plagues urban black communities must be understood as a consequence of poverty and racial oppression, particularly the labor-market marginality of black men (see also Sullivan 1983; Rainwater 1985). When linked to the above hypotheses about family structure and crime, the derived prediction is that black male adult employment and economic status will have important negative effects on black criminality that are mediated by family disruption. ${ }^{5}$ If this hypothesis is correct, it may explain the unexpected and vigorously

\footnotetext{
${ }^{5}$ Note that, even if some of the effect of economic status on family disruption is reciprocal, estimates of the direct effects of both of these factors on crime will be unbiased.
} 
debated finding in the criminological literature that unemployment and, to a lesser extent, economic deprivation have little or no direct effect on aggregate crime rates (see, e.g., Freeman 1983; Cantor and Land 1985; Messner 1982; Byrne and Sampson 1986). ${ }^{6}$ But, rather than being an anomaly, this outcome is expected under the present model.

I examine these hypotheses in a disaggregated analysis of the effects of the prevalence of black families headed by females in a community on both black juvenile and adult violence, controlling for theoretically specified alternative predictors (e.g., racial and age composition, density, region). To assess the generalizability of the theoretical model, I examine the effect of white family disruption on variations in rates of white violence where the data permit. To the extent that the major structural determinants of urban black violence similarly explain variations in white violence, this will then provide additional evidence counter to theories that derive their explanatory framework from unique aspects of black culture.

While there is a substantial literature on broken homes and individual delinquency (see Wilkinson 1980) and while the debate over family structure and its relationship to economic well-being is not new (see Wilson 1984), these structural hypotheses have not been empirically examined in previous research. In particular, few research efforts have examined the independent effects of family disruption on intercity variations in serious crime (see reviews in Harries 1980; Byrne and Sampson 1986), and of these none focused on racially disaggregated rates of black violence. And while my $(1985 a, 1986 b)$ research has demonstrated the importance of community family structure in predicting victimization rates and black offending rates, I did not consider the direct or indirect effects of the central theoretical factor of black male joblessness.

\section{DATA AND METHOD}

The units of analysis for this study are the 171 cities in the United States with a population greater than 100,000 in 1980 . The mean black population in these communities is $85,344 .{ }^{7}$ Raw data used to construct racially

\footnotetext{
${ }^{6}$ The relationship between crime and unemployment is especially weak in previous research using cross-sectional aggregate data. E.g., Orsagh (1980, p. 183) concluded that "the proper inference is that the effect of unemployment on crime rates is minimal at best" (see also Wilson and Herrnstein 1985, p. 313).

${ }^{7}$ A total population minimum of 100,000 was chosen to ensure the reliable estimation of serious offending rates in a racially disaggregated analysis. E.g., even though the present sample of cities has a mean total population of over 335,000 (mostly whites), the mean number of homicide arrests is only 65 . When disaggregated by race and age, offending estimates for serious crimes in smaller communities become unreliable.
} 
disaggregated measures of city characteristics were drawn from the U.S. Bureau of Census data tapes (STF3) and U.S. Bureau of Census (1982).

Because of the theoretical focus on communities and crime, the main indicator of area family structure is the percentage of total black households with female heads. That is, the interest is on the overall effect of an area's rate of marital and family disruption on both juvenile and adult crime. However, to assess further the disruption among families with children, I also examine the percentage of black households with children under 18 with female heads.

Following Wilson and Neckerman (1985, p. 28), I define a "male marriage pool index" (MMPI) as the number of employed black males per 100 black females. The number of women is used as the denominator to reflect differences across cities in the situation of women in the "marriage market." The major indicator of economic deprivation is black percapita income. A per-capita measure rather than median family income is used to avoid differences across cities and races in family size (see, e.g., Ross and Sawhill 1975, p. 82).

As noted by Ross and Sawhill (1975, p. 114), welfare benefits vary considerably across jurisdictions, a variation that may result in different forms of family structure (see also Honig 1974). Murray (1984), for example, argues that relaxed restrictions and high welfare payments entice lower-class black women to bear children out of wedlock and encourage the breakup of existing families since a female head is the major prerequisite for receiving Aid to Families with Dependent Children (AFDC) (for excellent reviews and analyses of this argument, see Ellwood and Bane [1984]; Ross and Sawhill [1975]). Therefore, to account for the possible effects of welfare on family disruption, I collected the mean public assistance payment to black families receiving assistance for each city and entered it as a control variable (U.S. Bureau of Census 1982). ${ }^{9}$

${ }^{8}$ Wilson and Neckerman $(1985$, p. 28) constructed the MMPI for several age-specific
categories, whereas the city-level measure pertains to both males and females 16 and
older. This does not seem to be a problem since median age of the black population is
controlled. In addition, a summary measure of employed black men is needed, and a
limitation to any one age group would be arbitrary. Note, however, that the use of
population that is 16 and older will artificially lower the mean level of the MMPI more
for whites than blacks. This is because the median age of whites is considerably higher
than the median age of blacks, and hence the denominator of the white MMPI will
contain proportionately more elderly females not in the marriage market (or of child-
bearing age) than the black MMPI.
${ }^{9}$ The welfare variable pertains to total public assistance payments (e.g., it includes aid
to the blind) and not just AFDC payments, because the latter measure was unavailable
for all cities. AFDC constitutes the vast majority of public assistance, however, and
consequently the present data are consistent with previous research using AFDC (see,
e.g., Ross and Sawhill 1975). E.g., cities in the South known to have low AFDC
payments (e.g., Huntsville, Houston, Dallas, Columbia, and Chattanooga) also record 
In reviewing the demographic literature, Wilson (1984, p. 98) also notes the relationship between the age composition of racial groups and differences in fertility, out-of-wedlock births, and economic status (see also Ross and Sawhill 1975, pp. 15, 212; Hogan and Kitagawa 1985; Ross and Sawhill 1975, p. 22; Bishop 1980). Therefore, median age of the black population is included as a control variable. Other measures of age composition (percentage of black females under 18) and a proxy indicator of fertility (number of black children under age five per black female under 55$)$ were correlated with median age $(-.78$ and -.62 , for percentage black females and fertility, respectively) and thus produced similar results.

The control variables that were not disaggregated were selected on the basis of past theory and research. First, region is controlled via dummy variables for both western and northern locations. The latter is related to levels of welfare payments and proportion of families headed by females (see, e.g., Ross and Sawhill 1975), while the former has been shown to be associated with high crime rates in the 1980s (Sampson 1986b) and high divorce rates (Ross and Sawhill 1975, p. 51). Second, racial composition (percentage black) is included in the model even though the crime rates are racially disaggregated. Curtis (1975) argues that the relative size of the black population is a critical factor in determining the emergence and solidification of the black subculture.

The natural $\log$ of population size (Mayhew and Levinger 1976) and structural density of housing units complete the vector of predictors (see reviews in Byrne and Sampson 1986). The density measure is defined as the percentage of housing units located in structures of five or more units. As I (1983) and Wilson (1984) have argued, in densely settled ghetto areas, especially housing projects, residents have difficulty recognizing their neighbors and may be less willing to engage in guardianship behavior. In addition, high structural density offers more places (e.g., stairwells, hallways, underground garages) to carry out criminal acts such as robbery, in the absence of capable guardians (Sampson 1983). To approximate the presence of housing projects and their anonymity, the density measure includes rental units rather than homeowner units.

Because of the high level of residential segregation by race in U.S. cities, the racially disaggregated measures reflect in essence the economic

the lowest public assistance payments in the present sample. Similarly, northern cities that allegedly attracted welfare clients because of their generosity (e.g., Newark, New York, Hartford, and Bridgeport) all have assistance payments well above the national mean. Also, DeFronzo (1983, p. 124) found that the correlation between AFDC and public-assistance payments in SMSAs was .87 and that both measures yielded similar results in multivariate analysis. The evidence is thus strong enough to justify the use of mean public assistance as a proxy for mean AFDC payments across cities. 
and family structures of the black and white communities across major cities. Indeed, the average level of racial segregation in American cities is greater than .80 (Sørensen, Tauber, and Hollingsworth 1975). As Guest (1984, p. 303) has recently observed: "The most accurate descriptive summary of residential distributions in American metropolitan areas would be in terms of a basic racial dichotomy, with blacks and whites largely occupying separate communities which rarely overlap." Further disaggregating the crime rate by race permits examination of the determinants of crime in black communities.

\section{Estimation of Black Offending Rates}

The crime data were made available by the FBI in the form of unpublished arrest counts by crime type and demographic subgroup for each police jurisdiction of the 171 cities for the years 1980-82. These data were then merged with the census files and used to estimate race-specific rates of criminal offending. Because official crime data have been the subject of numerous criticisms (see, e.g., Gove, Hughes, and Geerken 1985), in this section I explain the assumptions and evidence underlying the procedure.

First, Hindelang (1978) has systematically compared national UCR index arrest rates with offending rates estimated from National Crime Survey (NCS) victim surveys and found almost exact agreement. For example, Hindelang $(1978$, p. 100) found that $62 \%$ of the robbery offenders reported by victims were black, compared with an identical $62 \%$ of blacks arrested for robbery in UCR arrest data for the same year. Since racial correlates of arrest rates are the same for offending rates measured from a data source independent of the criminal justice system, we can have increased confidence in the validity of arrest reports.

Second, a large body of research on police-citizen encounters has found that seriousness of the crime is the strongest predictor of arrest (see Gottfredson and Gottfredson 1980; Gove et al. 1985). Although racial and SES factors appear to influence police contacts for common juvenile delinquency offenses such as vandalism and theft (Sampson 1986c), there is no evidence of racial bias in police arrest decisions for robbery and homicide. ${ }^{10}$ The present research thus limits testing to the most serious and reliably recorded of the seven UCR index crimes-homicide and robbery - thereby reducing the likelihood of bias.

One can still argue that official arrest data, even for serious crimes,

${ }^{10}$ In probably the most recent effort to obtain direct evidence on arrest risk, Blumstein, Cohen, and Visher (1986) have examined self-reports of both crime and arrests in conjunction with actual arrest records for a sample of serious offenders. They reported that "no substantial differences in arrest risk were found by race, age, or prior arrests" for the crime of robbery. 
may be contaminated by bias when compared across jurisdictions. Direct evidence on this issue is found in Messner and South (1986), who analyzed race-specific, city-level victimization data from the NCS and FBI arrest data for 26 cities from the early 1970s. Although homicide is of course not studied in a survey of victims, and the 26-city victimization data have validity problems of their own (Gove et al. 1985), Messner and South (1986) report a high correlation, .81, between black arrest rates for robbery and black offending rates estimated from reports of robbery victims. Since homicide is a more serious crime and has a higher arrest probability than robbery, we can reasonably assume that homicide arrest rates are even more accurate than robbery arrest rates. ${ }^{11}$

The available evidence clearly suggests, then, that, for very serious crimes, arrest data reflect the offending process. To account for remaining jurisdictional biases, I explicitly controlled variations across areas in arrest probability in the estimation procedures. Some police departments are simply more effective in making an arrest than are others (Sampson $1986 b$ ). For example, in the present data, the mean ratio of reported robbery offenses to robbery arrests is 4.18 , ranging from a low of 1.33 to a high of 15.14. Some recent research also suggests that arrest probability may vary with structural characteristics such as inequality and racial composition (Liska, Chamlin, and Reed 1985).

To account for these potential jurisdictional biases, I multiplied each raw arrest rate by the offense/arrest ratio of its jurisdiction to achieve an estimate of offending. In other words, each demographic-specific arrest rate is scaled up to (i.e., transformed into) an offending rate by the ratio of crime-specific offenses to arrests. The procedure assumes that offense data are measured on a comparable basis across cities and that there are no major differences among subgroups in arrest probability. The first assumption is valid because robbery and homicide offense data have been shown to be reliably and validly recorded across jurisdictions (Gove et al. 1985). Furthermore, there are no important differences between black and white robbery victims in crimes reported to police (Flanagan and McLeod 1983, p. 299). The second assumption is met by the findings noted above. Criticisms of arrest data are thus addressed by use of the information thought to be problematic (i.e., variations in arrest probability) to develop estimates of the offending process. ${ }^{12}$

${ }^{11}$ Although Sherman and Glick (1984) report some evidence of error in recording arrest data across jurisdictions, there was no evidence of systematic error, and the largest errors were associated with the misclassification of relatively minor crimes (e.g., assault, weapons offenses, and vandalism).

12 The method of adjusting the raw arrest rates was selected because it is theoretically preferable (e.g., the transformation approximates an offending rate) and also because it is consistent with a body of prior research using arrest records to examine criminal 
Using the above procedures in conjunction with population estimates from the 1980 census, I constructed race- and age-specific offending rates for robbery and homicide for each of the 171 largest cities in the United States for each of the years $1980-82 .{ }^{13}$ I am limited by FBI reporting rules, which do not permit calculation of age-race-sex rates and only allow a race breakdown by juvenile (under 18) and adult (18 and over) arrests. ${ }^{14}$ Because of potential year-to-year variations in reporting and recording practices, a three-year average rate was computed to stabilize random fluctuations and reduce missing data, a practice followed in previous research (see, e.g., Sampson 1985b, 1986b).

A handful of communities had too few blacks to construct reliable offending rates and racially disaggregated family and economic characteristics (e.g., Livonia, Michigan, had 17 black juveniles). Moreover, preliminary analysis repeatedly identified these cities as disproportionately influencing estimates of the parameter vector. ${ }^{15}$ Therefore, a selection criterion was imposed, in that a city had to have at least 1,000 blacks to qualify for analysis. After application of this criterion, the effective sample size for robbery is 156 cities, while for the homicide analysis missing FBI data further reduced the number of cities to 153.

Finally, to assess multicollinearity, I examined the diagonal elements of $\left(X^{\prime} X\right)^{-1}$. These elements, defined as $\left(1-R_{j}^{2}\right)^{-1}$, have been termed vari-

career offending patterns (see Cohen 1986). It is interesting, though, that preliminary results, with the use of raw arrest rates, did not diverge much from the results presented here nor did results from other estimating techniques (e.g., entering arrest probability directly into the equation). The reason appears to be the relatively weak relationship between city characteristics and the offense/arrest ratio.

${ }^{13}$ Gibbs and Ericksen (1976) argue that the denominator (city population) used in conventional crime rates may be inappropriate because noncity residents may be victimized in the city. This is not a problem in the present analysis, since offending rates rather than offense rates are estimated. The evidence clearly indicates that offenders tend to commit personal crimes of violence in or near their own neighborhoods and almost always in their city of residence (see Pyle 1974).

${ }^{14}$ If the proportion of the population known to be at low risk for serious offending (e.g., the elderly and young children) varies with city characteristics (e.g., racial composition), then estimates of the effects of these factors on offending may be biased. Therefore, each adult offending rate was constructed after elimination of those 65 and older from the denominator. Similarly, black and white juveniles under age 5 were removed from the denominator of the race-specific juvenile rates.

${ }^{15}$ All regressions were subjected to a case analysis to detect the possible importance of influential observations in estimating regression parameters. Specifically, Cook's "D" and "studentized residuals" (Cook and Weisberg 1980) were inspected for each city in each model. A case is defined as influential if its deletion from the model results in a substantial change in the estimate of the parameter vector. After the elimination of cities with fewer than 1,000 blacks where rates were unstable, no city exerted a disproportionate influence on the results. Natural logarithms of demographic-specific offending rates were also taken to reduce skewness and induce homogeneity of error variances. 
ance inflation factors (see Fisher and Mason 1981, p. 109) because they measure the amount that the variance in ordinary least squares (OLS) parameter estimates are inflated in the presence of multicollinearities. ${ }^{16}$ Commonly accepted practice regards variance inflation factors (VIF) above four $\left(K_{j}^{2}>.75\right)$ as an indicator of possible inefficiency in estimates (Fisher and Mason 1981, p. 109). In the present data, multicollinearity does not appear to be a serious problem, as no VIFs were greater than four. In addition, all bivariate correlations among exogenous predictors included in the same equations predicting black family structure and black offending were less than .60. Although the level of multicollinearity is thus fairly low, especially for city-level data (see Kennedy 1979, p. 131), this issue is addressed further in the analysis.

\section{RESULTS}

Table 1 presents basic descriptive statistics for the city data. It is clear that blacks fare much worse than whites with respect to mean income levels, employed men, and family disruption. For example, there are 10 more employed white males per 100 white women than for their black female counterparts; white per-capita income is $69 \%$ higher than blacks' on average; and, of central interest to the present study, the rate of black families headed by females is some $185 \%$ higher than for whites. The percentage of families with children headed by females is $146 \%$ higher for blacks than for whites ( $44 \%$ vs. $18 \%$ ). Overall, the racial differences are so great that, out of the 156 largest U.S. cities in the final sample, only one (Eugene, Oregon) has a percentage of black families headed by females at or below the mean percentage for whites; similarly, only three cities (Anchorage, Annaheim, and Bakersfield) have black per-capita incomes higher than the white mean. In contrast, the city with the highest rate of white family disruption (Bridgeport, Connecticut-14\%) is well below the black mean. These figures support Wilson's (1984) portrayal of urban black social dislocations.

Despite these large racial differentials, there is still considerable variation among black communities in economic and family structure and levels of violence. Indeed, reporting just mean levels tends to reinforce a conception of homogeneous black environments in the United States, which in turn engenders stereotypical and racist attitudes. For example, the percentage of total black households with a female head ranges from a low of $7 \%$ (Eugene) to a high of over 36\% (Newark and Milwaukee; the comparable range for families with children is $14 \%-60 \%$ ). Clearly, there

16 The quantity $R_{j}^{2}$ is the coefficient of determination resulting from the regression of the $j$ th predictor $x_{j}$ on the remaining $p-1$ predictors. 
TABLE 1

Descriptive Statistics of Structural Characteristics and Racially Disaggregated OfFending Rates, U.S. Cities, 1980

\begin{tabular}{|c|c|c|}
\hline Variable & $\bar{X}$ & SD \\
\hline \multicolumn{3}{|l|}{ Employed men per 100 women: } \\
\hline 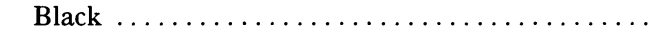 & 52.95 & 14.36 \\
\hline White $\ldots \ldots \ldots \ldots \ldots \ldots \ldots \ldots \ldots \ldots \ldots \ldots \ldots$ & 62.26 & 7.72 \\
\hline \multicolumn{3}{|l|}{ Mean public assistance income: } \\
\hline Black $\ldots \ldots \ldots \ldots \ldots \ldots$ & $2,565.44$ & 666.29 \\
\hline White $\ldots \ldots \ldots \ldots \ldots \ldots$ & $2,418.41$ & 367.13 \\
\hline \multicolumn{3}{|l|}{ Per-capita income: } \\
\hline Black ........ & $3,767.84$ & 708.79 \\
\hline White .... & $6,356.41$ & 998.88 \\
\hline \multicolumn{3}{|l|}{ Median age: } \\
\hline Black $\ldots \ldots \ldots \ldots \ldots \ldots \ldots \ldots \ldots \ldots \ldots \ldots \ldots \ldots \ldots \ldots$ & 24.48 & 1.78 \\
\hline White $\ldots \ldots \ldots \ldots \ldots \ldots \ldots \ldots \ldots \ldots \ldots$ & 31.81 & 3.48 \\
\hline \multicolumn{3}{|l|}{ Percentage of households headed by females: } \\
\hline Black $\ldots \ldots \ldots \ldots \ldots \ldots \ldots \ldots \ldots \ldots \ldots \ldots \ldots \ldots \ldots \ldots$ & 26.42 & 6.13 \\
\hline White $\ldots \ldots \ldots \ldots \ldots \ldots \ldots \ldots \ldots \ldots$ & 9.26 & 1.68 \\
\hline \multicolumn{3}{|l|}{$\begin{array}{l}\text { Percentage of households with children headed } \\
\text { by females: }\end{array}$} \\
\hline Black $\ldots \ldots \ldots \ldots \ldots \ldots \ldots \ldots \ldots$ & 43.58 & 9.52 \\
\hline White $\ldots \ldots \ldots \ldots \ldots \ldots \ldots \ldots \ldots \ldots \ldots \ldots$ & 17.69 & 3.70 \\
\hline \multicolumn{3}{|l|}{ Percentage of families on welfare: } \\
\hline Black $\ldots \ldots \ldots \ldots \ldots \ldots$ & 22.10 & 7.57 \\
\hline White $\ldots \ldots \ldots \ldots \ldots \ldots \ldots \ldots \ldots \ldots \ldots \ldots$ & 6.46 & 3.16 \\
\hline \multicolumn{3}{|l|}{ Region: } \\
\hline North ..... & .36 & .48 \\
\hline West ............ & .26 & .44 \\
\hline Percentage black $\ldots \ldots \ldots \ldots \ldots \ldots \ldots \ldots \ldots$ & 19.21 & 16.63 \\
\hline Population size $(l n) \quad \ldots \ldots \ldots \ldots \ldots \ldots \ldots$ & 12.31 & .76 \\
\hline \multicolumn{3}{|l|}{ Structural density of rental housing } \\
\hline 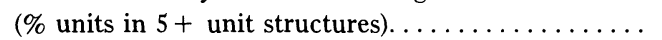 & 48.42 & 11.42 \\
\hline \multicolumn{3}{|l|}{ Homicide offending:* } \\
\hline Black juvenile $\ldots \ldots \ldots \ldots \ldots \ldots \ldots \ldots \ldots$ & $1.95(16.25)$ & 1.48 \\
\hline Black adult $\ldots \ldots \ldots \ldots \ldots \ldots \ldots \ldots \ldots$ & $4.32(91.67)$ & .64 \\
\hline \multicolumn{3}{|l|}{ Robbery offending: } \\
\hline Black juvenile $\ldots \ldots \ldots \ldots \ldots \ldots \ldots \ldots \ldots$ & $6.99(1,870.8)$ & 1.16 \\
\hline White juvenile $\ldots \ldots \ldots \ldots \ldots \ldots \ldots \ldots \ldots$ & $5.40(330.2)$ & 1.05 \\
\hline Black adult $\ldots \ldots \ldots \ldots \ldots \ldots \ldots \ldots$ & $7.54(2,371.8)$ & .67 \\
\hline White adult $\ldots \ldots \ldots \ldots \ldots \ldots \ldots \ldots \ldots$ & $5.46(308.3)$ & .74 \\
\hline
\end{tabular}

* Offending rates are log transformed; original metric (per 100,000) in parentheses. 
TABLE 2

OLS Regression Estimates of Equations Predicting Rates of Female-headed Black Households in U.S. Cities, 1980

\begin{tabular}{|c|c|c|c|c|}
\hline \multirow[b]{2}{*}{ StRUCTURAL CHARACTERISTICS } & \multicolumn{2}{|c|}{$\begin{array}{l}\text { PERCENTAGe OF Total } \\
\text { BlaCK HouseHOLds } \\
\text { WITH FEMALE HEAD }\end{array}$} & \multicolumn{2}{|c|}{$\begin{array}{c}\text { PeRCENTAGe of } \\
\text { BLACK HouseHolds } \\
\text { WITH CHILDREN } \\
\text { WITH FEMALE HEAD }\end{array}$} \\
\hline & $\beta$ & $t$-ratio & $\beta$ & $t$-ratio \\
\hline \multicolumn{5}{|l|}{ Employed black males } \\
\hline Mean black welfare payment...... & .21 & $3.53 * *$ & .27 & $4.21^{* *}$ \\
\hline Black per-capita income $\ldots . . . \ldots$ & -.18 & $-3.90 * *$ & -.39 & $-7.67 * *$ \\
\hline Black median age $\ldots \ldots \ldots \ldots \ldots$ & -.18 & $-3.62 * *$ & .09 & $1.69^{*}$ \\
\hline Percentage black $\ldots \ldots \ldots \ldots \ldots$ & .24 & $4.25 * *$ & .21 & $3.40 * *$ \\
\hline North..................... & .13 & $2.10^{* *}$ & .34 & $5.07 * *$ \\
\hline West. $\ldots \ldots \ldots \ldots \ldots \ldots \ldots$ & -.12 & -1.59 & .07 & .87 \\
\hline Structural density $\ldots \ldots \ldots \ldots \ldots$ & .00 & .03 & .10 & $1.87^{*}$ \\
\hline \multirow[t]{2}{*}{ Population size $\ldots \ldots \ldots \ldots \ldots$} & .01 & .18 & -.03 & -.56 \\
\hline & \multicolumn{2}{|c|}{$R^{2}=.75, P<.01$} & \multicolumn{2}{|c|}{$R^{2}=.70, P<.01$} \\
\hline
\end{tabular}

$* P<.10$.

** $P<.05$.

are communities where black family disruption is relatively rare or, conversely, unusually high. Similarly, black per-capita income ranges from a low of $\$ 2,272$ to a high of over $\$ 7,000$. The question, then, is whether and how these relative variations in structural context are linked to variations in criminal violence.

Table 2 presents the first-stage results of equations predicting variations in the percentage of black households headed by females. For the major indicator of family disruption (total black households with a female head), the strongest predictor by far is the black MMPI-net of all other factors, an increase in the pool of employed black men relative to black adult females tends to reduce rates of female heads substantially ( $\beta$ $=-.47$ ). The other results are largely consistent with the theoretical framework-rates of family disruption are higher in cities characterized by economic deprivation (i.e., low per-capita income), a low median age, high percentage of blacks, northern location, and a higher mean welfare payment. For families with children headed by females, the results are much the same except that per-capita income has a slightly greater effect than the marriage-pool indicator. In any event, the results clearly support the hypothesis that the chief determinants of black family disruption are embedded structural factors-economic deprivation and the small pool of employed black men. 
Table 3 presents the results for the prediction of criminal homicide. One notes that the strongest predictor of black juvenile homicide is family disruption (.41), followed by population size (.22). ${ }^{17}$ For black adult homicide, family disruption has a much weaker effect, and the strongest predictor is region. Specifically, black adult murder is significantly higher in western and northern cities, large cities, cities with low per-capita incomes, and, perhaps surprisingly, cities with low welfare payments. These age-specific differences suggest that family disruption has a stronger influence on juvenile crime than on adult crime. ${ }^{18}$

Although the MMPI has no direct effect on black juvenile homicide, it has a rather substantial $(-.19)$ indirect effect, mediated by family disruption. Male joblessness also has a nontrivial $(-.10)$ indirect effect on black adult homicide, mediated by family disruption. The results thus show that a simple comparison of the direct effects of family structure and economic variables on black crime is misleading, for the latter (especially, employed black males) appear to influence black juvenile crime indirectly. Failure to capture the complex interrelationships among structural characteristics will thus lead to an understatement of the relevance of unemployment and economic deprivation to explaining black criminality. Indeed, a host of recent publications have noted the unexpected finding that poverty and unemployment have weak or insignificant effects on aggregate crime rates (Orsagh 1980; Freeman 1983; Messner 1982; Cantor and Land 1985).

Table 4 presents the structural equation results for the prediction of black robbery rates. Again, family structure has the largest effect on black juvenile offending - the effect coefficient for black families headed by females is .55 and the $t$-ratio is greater than four. Black juvenile robbery rates are also strongly related to structural density and region but rather weakly related to median age, high black welfare payments, and low income. Indeed, the latter two effects are less than one-third the magnitude of the family disruption effect. As with murder, the effect of male joblessness is largely indirect. In fact, the large indirect effect of

${ }^{17}$ In cross-group comparisons, unstandardized regression coefficients are usually preferred. However, in the disaggregated analysis here, the values and variances of the independent variables are all the same-only the dependent variables differ. Therefore, for ease of presentation only standardized (path) coefficients are shown; inspection of the unstandardized $b$ 's did not yield any different interpretations.

${ }^{18}$ There appears to be some multicollinearity in the black adult homicide equation, as the $\beta$ for family disruption is fairly large but its $t$-ratio is insignificant (see Fisher and Mason 1981, p. 107). However, even if MMPI is dropped from both the juvenile and adult equations, the effect of family disruption is still twice as large for juveniles ( $\beta$ $=.40, P<.05)$ as for adults $(\beta=.19, P>.10)$ and unchanged in magnitude. This issue is addressed further below by specification of an alternative indicator of family disruption (families with children headed by females) that is less correlated with the MMPI (-.63 vs. -.74$)$. 


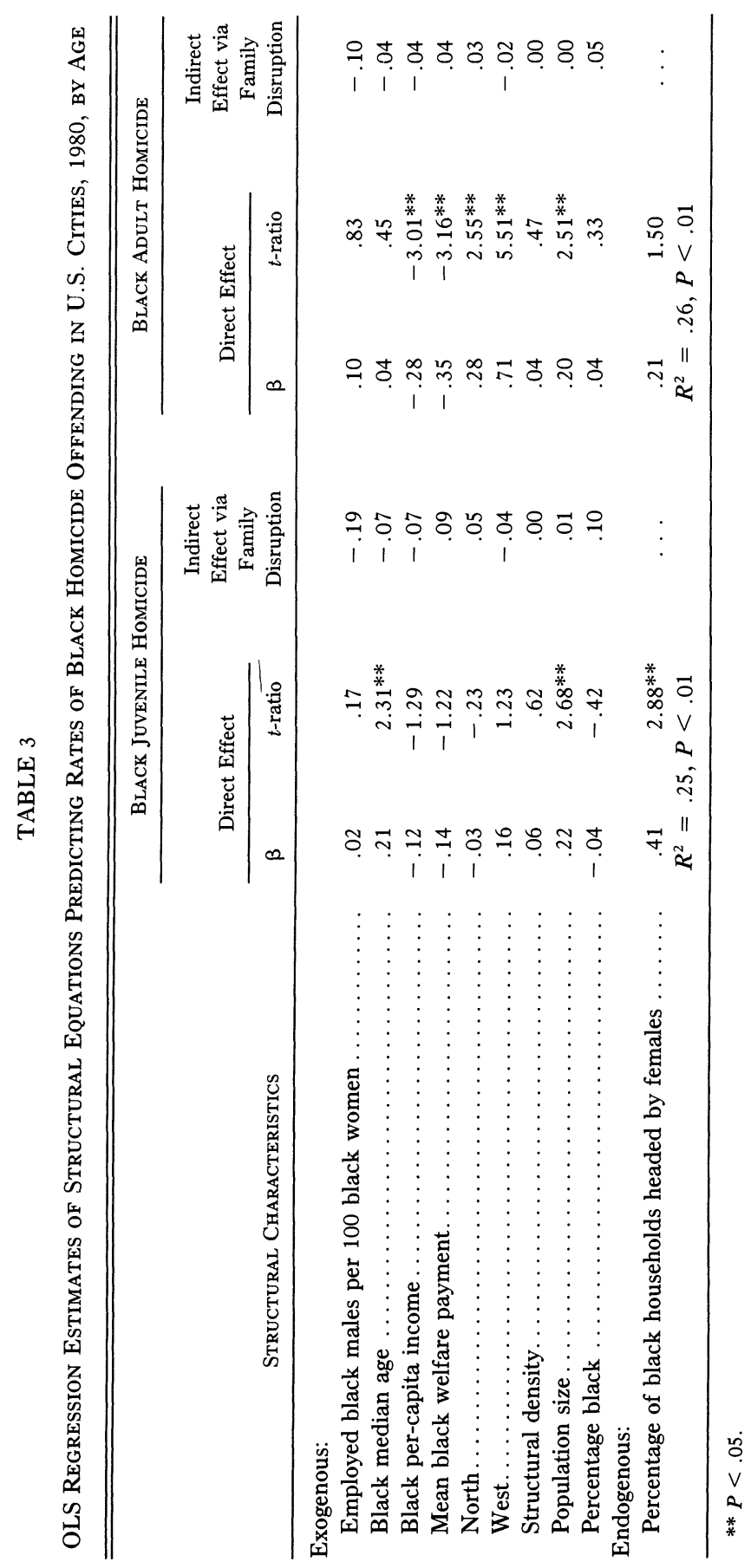




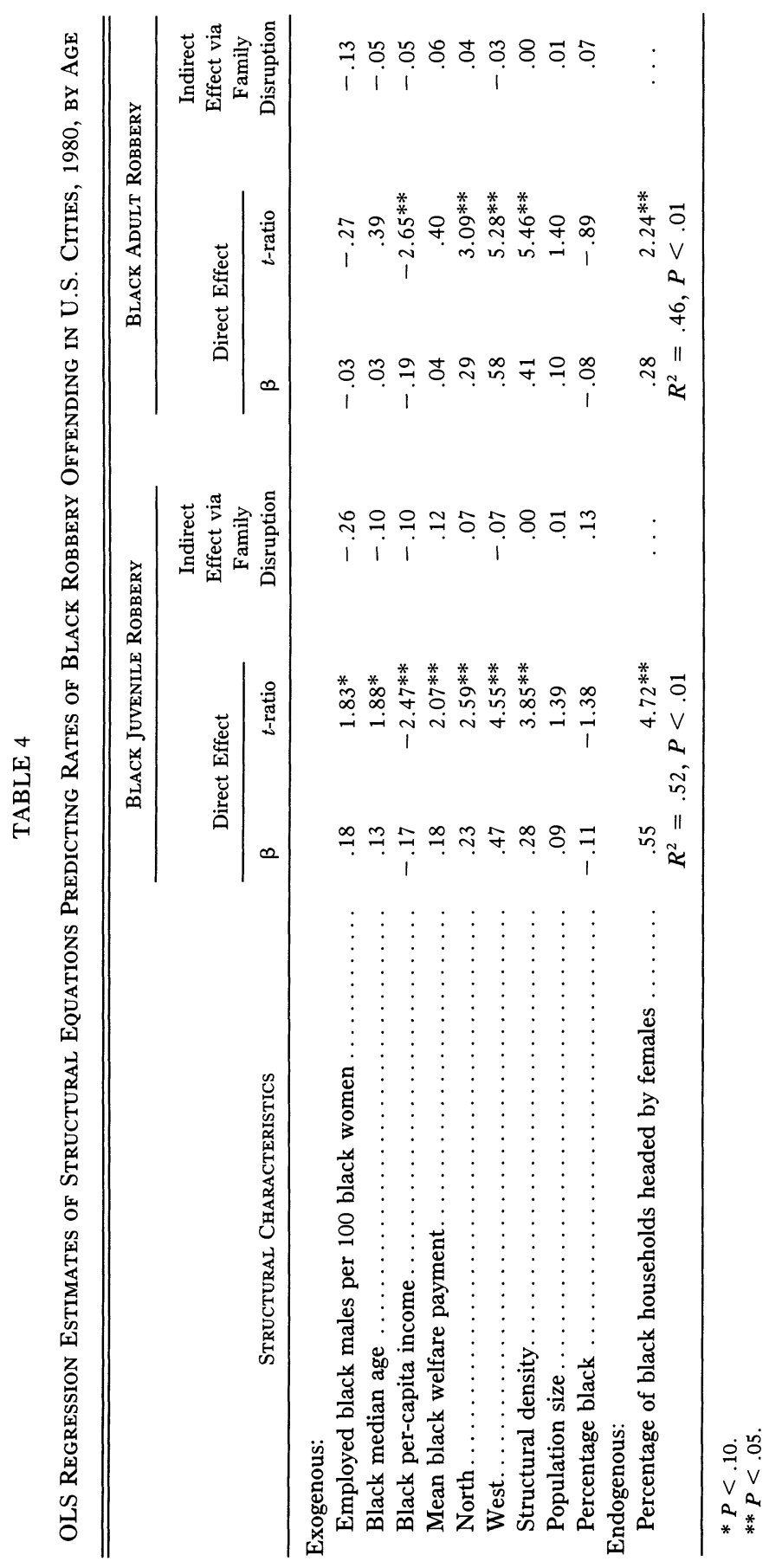


MMPI $(-.26)$ is twice the magnitude of any other indirect effect. The positive $(P<.10)$ direct effect may reflect increased criminal opportunities in areas of high employment (Cantor and Land 1985).

Black adult robbery is also significantly and positively related to the prevalence of black families headed by females, but the effect coefficient is half that of juvenile robbery. This difference between black juveniles and adults is statistically significant $(P<.05)$, thus again pointing to a differential effect of family structure on juvenile crime. Male joblessness has the largest indirect effect on black adult robbery, although this, too, is half the magnitude of the corresponding juvenile coefficient. The strongest predictors of adult robbery are western region and structural density of rental housing units.

Finally, note that the racial composition of cities is unrelated to variations in black offending for both age and crime types in tables 3 and 4. This pattern undermines the subculture-of-violence thesis that criminal violence should be higher where there is a relatively large black population (Curtis 1975). Instead, the data suggest that variations in black crime rates are largely attributable to structured inequalities in income and jobs, which in turn lead to high and persistent rates of family disruption. Race has contextual importance only insofar as the relative size of the black population has a moderate, positive effect on black family disruption.

To substantiate the validity of the above results, I repeated all regressions by introducing alternative predictors in an effort to detect possible problems with multicollinearity and to assess potential misspecification error. For example, the percentage of black families with income less than $\$ 7,499$ was entered in lieu of per-capita income as an indicator of poverty and economic deprivation. Although black poverty is even more highly correlated with families headed by females (.68) than is per-capita income $(-.39)$, the effects of family disruption were essentially identical (e.g., $\beta=.43$ and .53 for black juvenile murder and robbery, respectively). Racial income inequality (ratio of white to black per-capita income) was also entered in the model, but, since it was correlated with black per-capita income $(-.58)$, it did not change the results. Robustness tests with a southern dummy variable, residential mobility, and a racespecific measure of occupational status also failed to alter the general results, as did a series of models in which the direct effect of male joblessness was constrained to be zero. ${ }^{19}$

${ }^{19}$ Note also that, since most of the cities in the analysis are major urban centers that are not contiguous, spatial autocorrelation among the disturbance terms (see Kennedy 1979 , p. 80; Loftin and Ward 1983) is unlikely to be a serious problem. Nevertheless, to address this additional concern, I eliminated all cities with contiguous borders and repeated the analysis. Most of the 21 affected cities were smaller "satellite" cities of 
It is also possible that crime rates may be influenced not so much by the economic level of welfare payments as by the prevalence of welfare families in the community. In particular, a high prevalence of economic dependence in a community may reflect overall social disorganization and a breakdown in social control (see esp. Kornhauser 1978), which may account for both family disruption and crime rates. The prevalence of welfare families and the mean welfare payment share only $25 \%$ common variance, suggesting that the prevalence measure is in fact tapping a somewhat different dimension of community structure from that of benefit payments. To control for this possibility, I reestimated the regressions in tables 3 and 4 by substituting the percentage of total black families receiving public assistance for the mean level of welfare benefits. Although this variable is more highly correlated (as expected) with families headed by females (.77) and hence presents a severe test, the effects of female heads of families should be distinguishable if the theory is correct.

The results of the alternative structural model in table 5 are unequivocal. The effect of families headed by females is in all cases similar to the effects noted earlier-significant and positive, especially with regard to black juvenile crime. Inspection of the unstandardized coefficients reveals that the effects of family disruption on black juvenile violence are approximately three times the magnitude of the effects for black adult violence. In any case, the effect of family disruption is not due to the level of community disorganization (when we use economic dependence as a proxy). In fact, the effect of welfare families is insignificant for all but black adult homicide, and here the effect is negative (cf. table 3). The results of this test, in conjunction with the tests for poverty, inequality, and residential mobility (the last of which has also been argued to reflect community disorganization [Kornhauser 1978; see also Bursik and Webb 1982]), tend to suggest strongly that the effect of family disruption on crime is not due to common third causes.

\section{White Family Disruption}

If the causal influences of family disruption are related to the general processes of social control, as hypothesized, and are not simply unique to the black community (e.g., matriarchal culture, black family socialization), then variations in rates of white families headed by females should also predict variations in white crime. Therefore, as a further test of the

major metropolitan areas (e.g., Glendale, Garden Grove, and Pasadena in L.A. county). The results were substantively identical to the above results. 


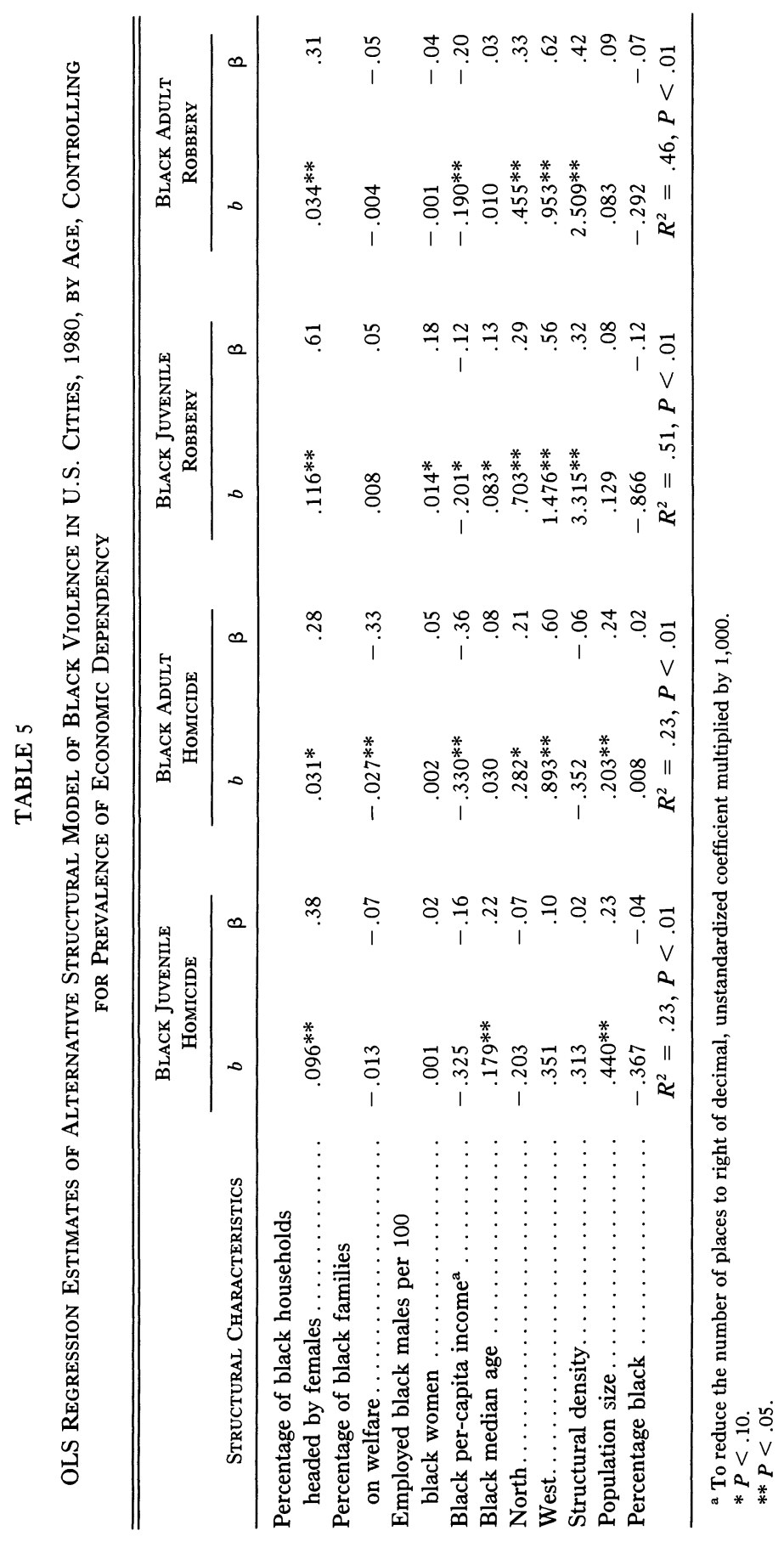


theory, the effects of white family structure on white robbery are examined and compared with a similar model for black robbery. ${ }^{20}$

In a comparison of black and white models, there are reasons to expect that the disturbance terms from both crime equations are correlated. In the present data, such correlations may arise if there are common structural causes of black and white crime not included in the model. This is likely to happen since both black and white robbery rates pertain to the same geographical unit (cities). The case of correlated disturbances across equations in which endogenous variables are not causally linked is referred to as a system of "seemingly unrelated regressions" (see Kmenta and Gilbert 1971; Hargens 1986). When the exogenous variables in such equations are identical (e.g., tables 3-5), then OLS provides the best linear unbiased estimates (Hargens 1986), and no gain in efficiency is made by estimating residual covariations across subgroups. In contrast, when exogenous variables differ across equations (e.g., black-white models), OLS estimates are no longer efficient; furthermore, when comparisons of causal coefficients are made, OLS estimation procedures are erroneous because such tests assume uncorrelated disturbances across equations (Hargens 1986).

Therefore, to assess the structural determinants of white and black robbery, I estimated a "seemingly unrelated regression" (SUR) model by employing a maximum-likelihood covariance structure procedure (LISREL) that allows correlated disturbances (see Hargens 1986). The results indicate that the residuals of black and white violence are indeed strongly and positively correlated. Specifically, the changes in $\chi^{2}$ that result from freeing the parameters representing the between-race error covariances were 8.85 and 64.39 for juvenile robbery and adult robbery, respectively. Relative to one $d f$, the improvement in fit is significant at the .01 level. The corresponding standardized covariances are $.12(t$-ratio $=2.9)$ and $.35(t$-ratio $=6.25)$ for juveniles and adults, respectively. Hence, I conclude that the sources of black and white robbery not in the models are positively related. This finding further repudiates the idea, stemming

${ }^{20}$ A complete examination of black-white differences in the effects of structural characteristics on criminal offending is beyond the scope of this paper. A major reason for this stems from the inherent difficulty in studying serious criminal violence among whites. For example, white juvenile homicide rates are highly unreliable because of the extremely low frequency (the mean number of arrests for white juvenile murder is smaller than three). The specific goal in this section is thus limited to comparing the direct effects of the central theoretical factor-family disruption-on white and black robbery rates (for a more extensive comparison of other factors, see Sampson [1986b]). Also, to assess the sensitivity of the analysis to the definition of family disruption, I examined percentage of both total households and households with children headed by a female. The latter results are presented to provide a further check on the general patterns shown in tables 3-5 with regard to total family disruption. 


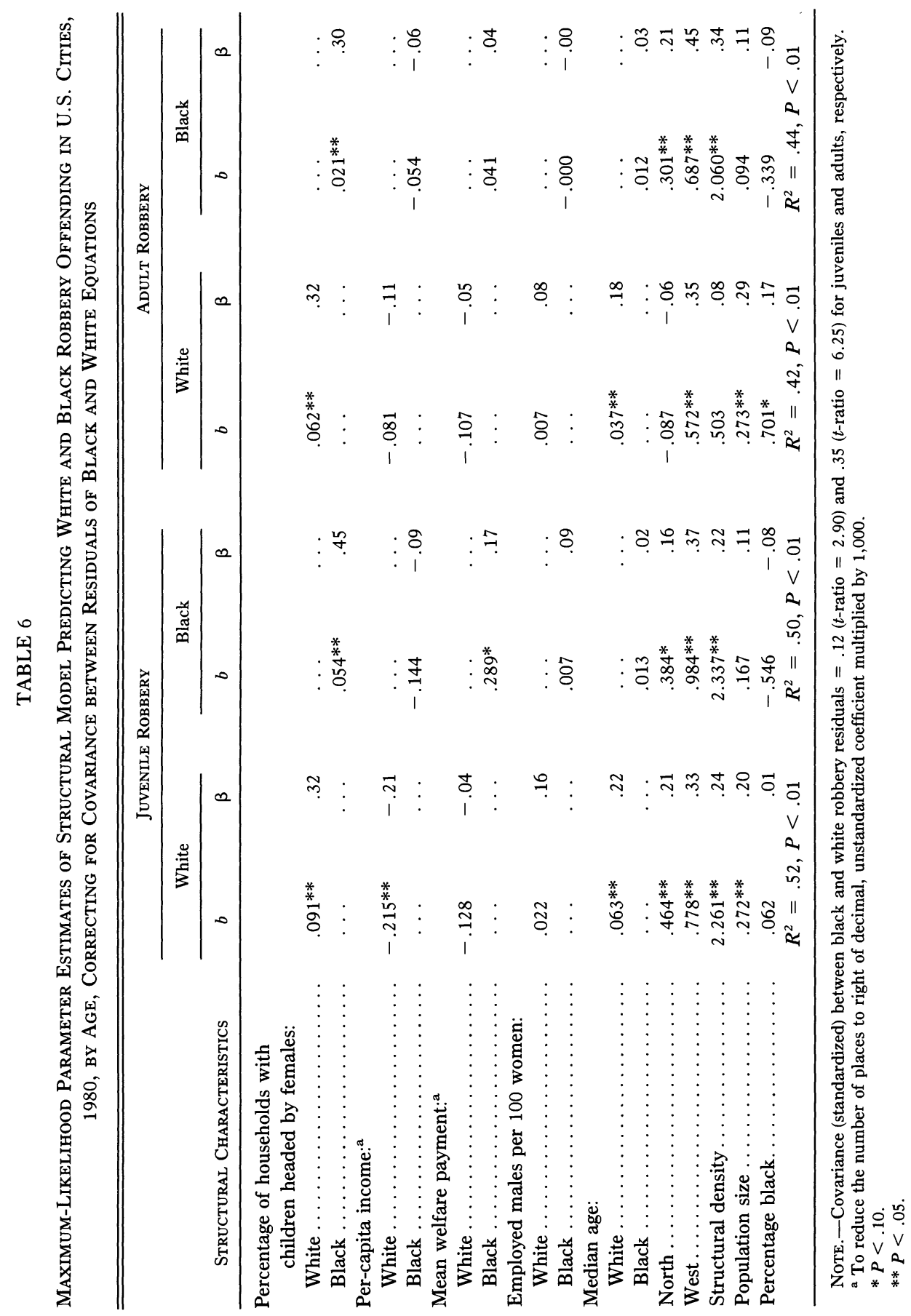


from the subculture-of-violence theory, that the causes of black crime are rooted in unique aspects of black culture.

Table 6 presents the maximum-likelihood parameter estimates of the SUR structural model. The results for the variables of central theoretical concern are strikingly similar across race. First, note that family disruption has large positive effects on both black and white juvenile robbery. While the unstandardized coefficient for whites is slightly larger than that for blacks, the difference is not significant when the parameters are constrained to be equal $\left(\chi^{2}\right.$ change $\left.=1.89,1 d f\right)$. Note also that region and density are the other major predictors of both black and white juvenile robbery, while MMPI and welfare have either insignificant or weak direct effects.

The results for adult robbery are also generally similar across race. Family disruption has significant and substantial effects on both black and white adult robbery. It is interesting to note that the effect of white family disruption is larger than the effect of black family disruption (.06 vs. .02), a difference that is statistically significant $\left(\chi^{2}\right.$ change $=7.41$, $1 d f) .{ }^{21}$ The other major determinants of black and white adult robbery are region, and size or density, whereas the direct effects of male joblessness, income, and welfare are insignificant. ${ }^{22}$

Black-white models were also estimated for adult homicide, with similar results: family disruption had significant positive effects on both black adult homicide (.27) and white adult homicide (.20). Furthermore, substitution of percentage total families headed by females also yielded substantively identical results. For example, the standardized effect of total black families headed by females on black adult robbery was .24 compared with .28 for total white families headed by females and white adult robbery (residual correlation $=.34, P<.01$ ). Apparently, then, the criminogenic consequences of family disruption are generic and thus not rooted in subcultural characteristics of black ghettos. ${ }^{23}$

${ }^{21}$ Note that in comparing causal coefficients one is assuming that family disruption has equivalent measurement properties across race. Since the census has been known to undercount blacks in urban centers, this may not be a reasonable assumption. Hence, the finding that white family disruption has a slightly larger effect is interesting but not definitive; the crucial empirical finding is that both white and black family disruption have significant and strong positive effects on criminal violence.

${ }^{22}$ Of all factors, the effects of per-capita income on both white and black violence were most attenuated when the residuals were allowed to covary. This suggests that previous research assuming uncorrelated errors between black and white crime rates (e.g., Sampson 1985b) may have overstated the direct effects of economic factors.

${ }^{23}$ It is worth noting that white per-capita income is more important than the white MMPI in predicting white families with children headed by females $(\beta=-.55$ and -.19 , respectively). Hence, the indirect effect of the white MMPI on white robbery, mediated by white family disruption, is smaller than income (e.g., -.06 and -.12 for 


\section{Community Crime and Family Structure: Simultaneous Causation?}

A final substantive problem concerns the possible reciprocal causation of family disruption and crime in the black community. Although various attempts have been made to eliminate alternative explanations of the effect of family disruption on crime, the models presented may be too simplistic in their recursive assumptions. For example, cities with high crime rates may have high incarceration rates for black males, which would tend to exacerbate marital and family disruption (cf. Wilson and Neckerman 1986, p. 27). Even if offenders are not caught or incarcerated, young women may not wish to marry into the criminal element, for males engaged in serious criminal activity in all likelihood make unstable and undesirable mates. Crime may also reflect general community disorganization not tapped by the other control variables. Thus, although crime in general is a rare phenomenon, the rate of black violence is sufficiently high that it may influence family structure (cf. Lane 1986); if so, the earlier parameter estimates are biased, and the effect of family disruption on crime is overstated.

To address this issue, I relaxed the assumptions of recursive causation and uncorrelated disturbances between family structure and crime and estimated a simultaneous equation model. As is well known (Kennedy 1979, pp. 106-12; Fisher and Nagin 1978, p. 368), the estimation of simultaneous models requires the judicious choice of a priori theoretical assumptions regarding parameter specification. Fortunately, the theoretical and empirical framework developed throughout this paper suggests an underlying model. First, the empirical results suggest that the overall direct effect of welfare on black crime is weak and inconsistent. ${ }^{24}$ More important, there is little theoretical support in the criminological literature for assuming that the level of welfare payments directly affects the crime rate. Even the most vocal critics of welfare (e.g., Murray 1984) do not suggest that welfare directly increases crime but rather argue that increased welfare benefits encourage the formation of families headed by females. Therefore, the mean black welfare payment is assumed to influence crime indirectly through family disruption, thus qualifying as an

white juvenile robbery). Although further examination of the determinants of white family structure is not possible here, this finding is consistent with Wilson's general thesis that structural unemployment is a more important factor in accounting for black than for white family disruption (Wilson 1978).

${ }^{24}$ Recall that welfare had no effect on black juvenile homicide and black adult robbery, a negative effect on black adult homicide, and a positive effect on black juvenile robbery. Hence, the overall direct effect of welfare on black violence appears to be null; indeed, a reestimate of the structural model in tables 3 and 4 utilizing a total black violence rate reveals an insignificant effect of welfare. 
identification restriction in the equation predicting black criminal offending. ${ }^{25}$

Second, the theoretical model posited that increasing size and density directly increase the rate of criminal violence (see Mayhew and Levinger 1976; Sampson 1983). In contrast, there is little if any theoretical or empirical support in the literature on family disruption for concluding that city size and housing density are directly related to the formation of families headed by females among urban residents (see Ross and Sawhill 1970, pp. 15-16, 213; Loftin and Ward 1983). Indeed, table 2 reveals that neither size nor density had significant $(P<.05)$ effects on family disruption; for example, the $\beta$ coefficients reflecting the effects of size and density on total families headed by females were .00 and .01 , respectively. Therefore, the assumption is invoked that size and density influence family disruption only through their effects on the crime rate, which allows identification of the full simultaneous model.

Using these theoretical restrictions, I estimated a two-stage least squares (2SLS) simultaneous model of black violence and family disruption. Since my interest is in the overall effect of community violence on family structure, both robbery and homicide offending by black juveniles and adults were incorporated into a black violence rate. This, in conjunction with the respecified simultaneous model, provides an overall refined test of the theoretical framework. The schematic representation of the model and the significant parameter estimates for exogenous factors are shown in figure $1 .^{26}$

The 2SLS results corroborate the original theory-the effect of family disruption on black violence is strongly positive and not due to the confounding reciprocal effect of crime itself. For example, while the effect of black violence on families with children headed by females is positive and marginally significant $(\beta=.14, P=.10)$, the simultaneous effect of black family disruption on violence is four times greater (.56). The corre-

${ }^{25}$ One could exclude male joblessness from the crime equation because it, too, had generally insignificant direct effects on black crime. However, it is difficult to make a plausible theoretical argument that employment and SES factors do not directly affect crime. As emphasized by Fisher and Nagin (1978, p. 372), identification restrictions must ultimately be justified on a priori theoretical grounds, for the validity of restrictions can never be empirically tested with the use of data generated by the model under consideration. For this reason, welfare appears to be the most plausible exogenous variable to exclude from the crime function.

${ }^{26}$ In 2 SLS analysis, multicollinearity problems generally become aggravated with regard to the endogenous predictors, and thus caution should be exercised in interpretation. Fig. 1 emphasizes the model with percentage black families with children headed by females because its predicted values share less overlap with the exogenous variables (especially MMPI) than total families headed by females. The corresponding estimates for total family disruption (in parentheses) are much the same, however. 


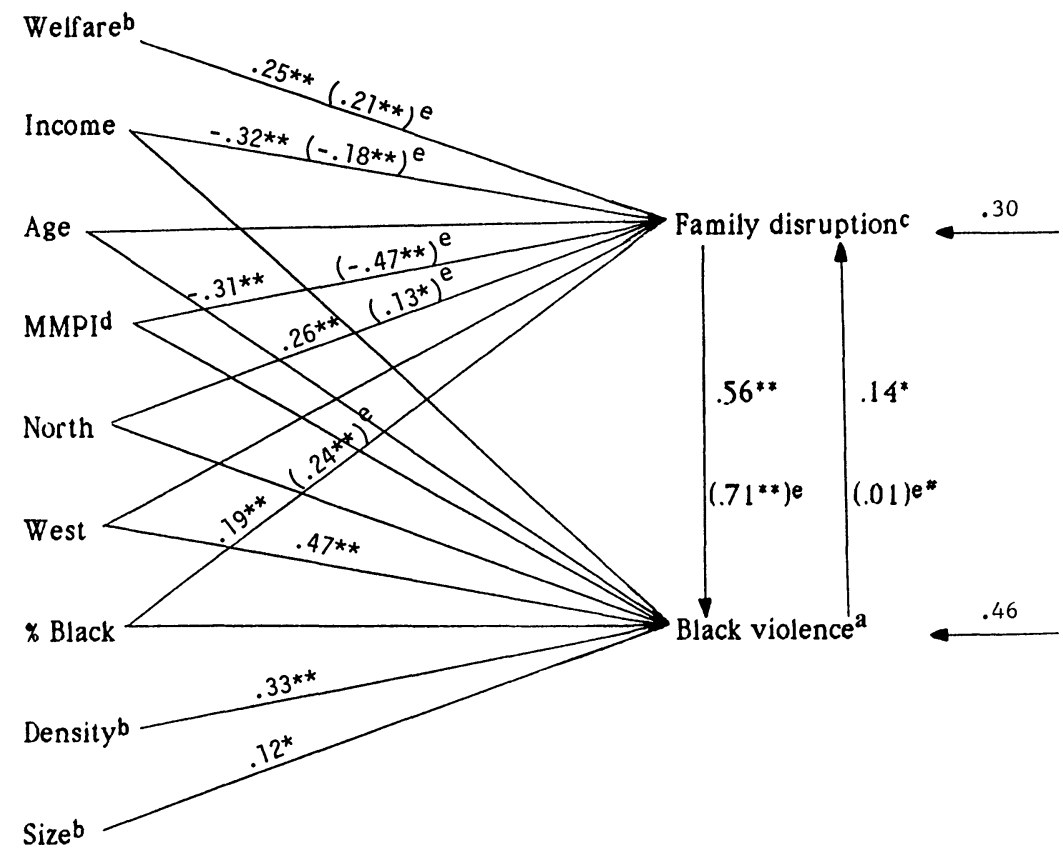

FIG. 1.-2SLS parameter estimates of simultaneous structural model of black violence and family disruption in U.S. cities, 1980 (significant exogenous coefficients only): $a$, Includes homicide and robbery by blacks; $b$, Identification restrictions; $c$, Percentage of black households with children headed by females; $d$, Male marriage pool index (employed black males per 100 black females); $e$, Parameter estimates for percentage of total black households with a female head. ${ }^{*} P<.10 .{ }^{* *} P<.05$. ${ }^{\#} \mathrm{NS}$.

sponding effect of total households headed by females on black violence is even stronger (.71), while the reciprocal effect is null. Also consistent with the underlying theoretical model, density has a significant (.33) effect on black violence and welfare on family disruption (.25), which indicates that the analysis does not suffer from the choice of weak instrumental variables.

Further, the results again establish the importance of male joblessness. Independent of both community crime and other controls, MMPI has large negative effects on disruption in families with children $(-.31)$ and on total family disruption (-.47). Consequently, the indirect effects of MMPI on black violence through these two indicators of family disruption are substantial: -.17 and -.33 , respectively. The corresponding indirect effects for per-capita income are -.18 and -.13 . Within the 
limitations of the data and theoretical assumptions, then, the empirical results suggest that, despite the influences of community crime and its associated social dislocations, male joblessness and economic deprivation have important effects on family disruption, which in turn has a strong reciprocal effect on black violence in urban areas. ${ }^{27}$

\section{SUMMARY}

The manifestations of the black "underclass" have been frequently discussed in recent literature but rarely empirically examined in a systematic theoretical framework, especially a structural one. T'o redress this imbalance, the present study has attempted to link Wilson's theory of the structural determinants of black family disruption with a macrolevel perspective on communities and crime. The empirical test of the model departed from previous research by $(a)$ racially disaggregating the crime rate across U.S. cities, $(b)$ explicitly focusing on the exogenous factors of black male joblessness and economic deprivation, and $(c)$ examining the mediating effect of black family disruption on black urban violence.

Overall, the analysis supports the main hypothesis and shows that rates of black violent offending, especially by juveniles, are strongly influenced by variations in family structure. Independent of the major candidates supplied by prior criminological theory (e.g., income, region, size, density, age and race composition), black family disruption has the largest effects on black juvenile robbery and homicide. Family disruption also has a small effect on black adult homicide and a relatively strong positive influence on black adult robbery.

The consistent finding, that family disruption has stronger effects on juvenile crime than on adult crime, in conjunction with the inconsistent findings of previous research on individual-level delinquency and broken homes (see Wilkinson 1980; Ross and Sawhill 1975), tends to support the idea that the effects of family structure are related to macrolevel patterns of social control and guardianship, especially regarding youths and their peers (Sampson 1986b; Felson and Cohen 1980; Felson 1986). However, it should be emphasized that definitive resolution of the mechanisms

\footnotetext{
${ }^{27}$ To assess the sensitivity of results to model specification and to reduce multicollinearity, I conducted further analysis on black adult robbery. Robbery is much more prevalent than homicide (and hence more likely to influence family disruption), and in addition robbery by black adults was not directly affected by either welfare or the MMPI (see tables 4 and 5). After I excluded these two variables from the crime function, the 2 SLS results were consistent with fig. 1-both indicators of family disruption had significant positive effects on black adult robbery.
} 
linking family disruption with crime rates must await further research, for direct measures of the hypothesized macrolevel mediating constructs (e.g., informal community supervision of peer groups, patterns of formal social control) are not currently available.

Despite this limitation, the analysis has demonstrated that the effects of family structure are strong and cannot be easily dismissed by reference to other structural and cultural features of urban environments. Indeed, the results remain consistent-regardless of the addition of potentially confounding variables such as economic dependence, mobility, and inequality - and a simultaneous equation model supports the claim that the effect of family disruption on black violence is not due to a reciprocal effect of black violence on family structure.

Perhaps most interesting, the results also reveal that, despite a tremendous difference in mean levels of family disruption between black and white communities (table 1), the percentage of white families headed by females has a strong positive effect on white juvenile and adult robbery offending. In fact, the predictors of white robbery are in large part identical in sign and magnitude to those for blacks. Even the residuals of the black and white models are positively related, again suggesting that there are common structural factors that account for variations in criminal violence. Therefore, the analysis strongly points to the conclusion that the effect of family disruption on black crime is independent of commonly cited alternative explanations (e.g., poverty, region, urbanization, age and race composition) and cannot be attributed to unique cultural factors in the black community. Accordingly, the weight of the evidence raises serious questions about the empirical adequacy of subcultural theories of black violence.

Finally, the results provide a possible solution to the mystery of why unemployment and economic deprivation have been shown to have weak and inconsistent effects on crime rates in past research. For one, previous research has not disaggregated crime rates by race. More important, though, the effects of black male joblessness and economic deprivation on crime appear to be mediated in large part by family disruption. In other words, while male joblessness has little or no direct effect on crime, it has the strongest overall effect on family disruption, which in turn is the strongest predictor of black violence. The empirical evidence for blacks in large U.S. cities thus suggests that current popular explanations of family disruption (e.g., Murray 1984) have overstated the role of liberal welfare policies and played down what appear to be the most crucial factors-the extraordinarily high levels of black poverty and male joblessness (see Aponte, Neckerman, and Wilson 1985, p. 14). In conjunction with the tendency of criminological theory to cling to the individualistic and ra- 
tional choice idea that unemployment directly increases the motivation to crime (see, e.g., Freeman 1983), past research has failed to uncover the complex nature of the interplay among the economic marginality of black males, family structure, and crime.

\section{CONCLUSION: SOCIAL IMPLICATIONS}

Given the high and increasing rates of separation, divorce, out-ofwedlock birth, and joblessness among blacks compared with whites (Wilson 1981, 1984; Kasarda 1983, 1985; Hogan and Kitagawa 1985), the theoretical framework and empirical evidence from this study suggest that current social policy agendas are potentially quite misleading. Rather than our turning back the clock on welfare legislation, as advocated by the conservative Right, or ignoring high rates of black crime, as is common in the liberal sociological community, the data suggest that social policies be directed toward the structural forces of economic deprivation and labor-market marginality faced by black males and the resulting consequences for family disruption and community crime. Obviously, a detailed discussion of such policies is much beyond the scope of this paper, and the limitations of the present research caution against overgeneralization. Indeed, the issues I examine here are exceedingly complex, and nonexperimental research cannot hope to disentangle causal effects conclusively. Still, it seems that policies designed to retool unskilled workers, job supports, and a coherent family policy aimed at addressing the severe hardships faced by single women with children (especially those who work) are more likely to reduce family disruption and crime in the long run than are current policies aimed simply at reducing welfare and incarcerating an ever-increasing proportion of the black population. In fact, high rates of black male incarceration (Bureau of Justice Statistics 1985c) will probably only serve to exacerbate black family disruption through their effect on the black male marriage pool (Wilson 1984).

If current trends and policies on joblessness continue, the results do not bode well for the future, for the recent health of the American economy has been in large part at the expense of the unskilled and predominantly black work force in central cities. As Kasarda argues, "Chronically high unemployment will plague large portions of the urban underclass so long as the demographic and job-opportunity structure of the cities continue to conflict" (Kasarda 1983, p. 44). Therefore, it appears that the extremely high level of black violence in American cities cannot be separated from the equally pressing problems of black male joblessness and family disruption. To do so will, in all likelihood, lead to continued repressive crime-control measures and escalating violence. 


\section{REFERENCES}

Aponte, Robert, Kathryn Neckerman, and William Julius Wilson. 1985. "Race, Family Structure and Social Policy." Working Paper, Ogburn/Stouffer Center for the Study of Population and Social Organization, University of Chicago.

Bane, Mary Jo. 1985. "Household Composition and Poverty: Which Comes First?" Paper presented at the conference Poverty and Policy: Retrospect and Prospects, Williamsburg, Va. (In Antipoverty Policies: What Works and What Doesn't, edited by S. Danziger and D. Weinberg. Cambridge, Mass.: Harvard University Press [in press]).

Bishop, John. 1980. "Jobs, Cash Transfers and Marital Instability: A Review and Synthesis of the Evidence." Journal of Human Resources 15:301-34.

Blau, Judith, and Peter Blau. 1982. "The Cost of Inequality: Metropolitan Structure and Violent Crime." American Sociological Review 47:114-29.

Bloom, B. 1966. "A Census Tract Analysis of Socially Deviant Behaviors." Multivariate Behavioral Research 1:307-20.

Blumstein, Alfred. 1982. "On the Racial Disproportionality of United States' Prison Populations." Journal of Criminal Law and Criminology 73:1259-81.

Blumstein, Alfred, Jacqueline Cohen, and Christy Visher. 1986. "Linking the Crime and Arrest Process to Measure Individual Crime Rates." Paper presented at the National Institute of Justice Annual Conference on Prediction, Denver, Colorado, April.

Bureau of Justice Statistics. 1985a. "The Risk of Violent Crime." U.S. Department of Justice Special Report. Washington, D.C.: Government Printing Office. 1985b. "Capital Punishment, 1984." U.S. Department of Justice Special Report. Washington, D.C.: Government Printing Office. 1985 c. "The Prevalence of Imprisonment." U.S. Department of Justice Special Report. Washington, D.C.: Government Printing Office.

Bursik, Robert J., and Jim Webb. 1982. "Community Change and Patterns of Delinquency." American Journal of Sociology 88:24-42.

Byrne, James, and Robert J. Sampson. 1986. "Key Issues in the Social Ecology of Crime." Pp. 1-22 in The Social Ecology of Crime, edited by J. Byrne and R. Sampson. New York: Springer-Verlag.

Cantor, David, and Kenneth Land. 1985. "Unemployment and Crime Rates in the Post-World War II United States." American Sociological Review 50:317-32.

Cartwright, D., and K. Howard. 1966. "Multivariate Analysis of Gang Delinquency." Multivariate Behavioral Research 1:321-71.

Cohen, Jacqueline. 1986. "Research on Criminal Careers: Individual Frequency Rates and Offense Seriousness." Pp. 292-418 in Criminal Careers and "Career Criminals," edited by Alfred Blumstein, Jacqueline Cohen, Jeffrey Roth, and Christy Visher. Washington, D.C.: National Academy.

Cohen, Lawrence, and Marcus Felson. 1979. "Social Change and Crime Rate Trends: A Routine Activities Approach." American Sociological Review 44:588-607.

Cook, Dennis, and Sanford Weisberg. 1980. "Criticism and Influence Analysis in Regression." Pp. 313-61 in Sociological Methodology 1980, edited by Samuel Leinhardt. San Francisco: Jossey-Bass.

Curtis, Lynn. 1975. Violence, Race, and Culture. Lexington, Mass.: Heath.

Cutright, P. 1971. "Income and Family Events: Marital Instability." Journal of Marriage and the Family 33:291-306.

DeFronzo, J. 1983. "Economic Assistance to Impoverished Americans: Relationship to Incidence of Crime." Criminology 21:119-36.

Elliott, Delbert, and Suzanne Ageton. 1980. "Reconciling Race and Class Differences in Self-Reported and Official Estimates of Delinquency." American Sociological Review 45:95-110. 
Ellwood, D., and M. J. Bane. 1984. "The Impact of AFDC on Family Structure and Living Arrangements." U.S. Department of Health and Human Services grant 92A-82.

Ensminger, M.E., S. G. Kellam, and B. Rubin. 1983. "School and Family Origins of Delinquency: Comparisons by Sex." In Antecedents of Aggression and Antisocial Behavior, edited by K. T. Van Dusen and S. A. Mednick. Boston: Kluwer-Nijhoff.

Felson, Marcus. 1986. "Linking Criminal Choices, Routine Activities, Informal Social Control, and Criminal Outcomes." Pp. 119-28 in The Reasoning Criminal, edited by R. Clarke and D. Cornish. New York: Springer-Verlag.

Felson, Marcus, and Lawrence Cohen. 1980. "Human Ecology and Crime: A Routine Activity Approach." Human Ecology 8:389-406.

Fisher, Joseph, and Robert Mason. 1981. "The Analysis of Multicollinear Data in Criminology." Pp. 99-125 in Methods in Quantitative Criminology, edited by James A. Fox. New York: Academic.

Fisher, Franklin, and Daniel Nagin. 1978. "On the Feasibility of Identifying the Crime Function in a Simultaneous Model of Crime Rates and Sanction Levels." Pp. 361-99 in Deterrence and Incapacitation: Estimating the Effects of Sanctions on Crime Rates, edited by Alfred Blumstein, Jaqueline Cohen, and Daniel Nagin. Washington: National Academy.

Flanagan, Timothy, and Maureen McLeod, eds. 1983. Sourcebook of Criminal Justice Statistics, 1982. Washington, D.C.: Government Printing Office.

Freeman, Richard B. 1983. "Crime and Unemployment." Pp. 89-106 in Crime and Public Policy, edited by James Q. Wilson. San Francisco: ICS.

Gibbs, Jack, and Maynard Erickson. 1976. "Crime Rates of American Cities in an Ecological Context." American Journal of Sociology 82:605-20.

Gottfredson, Michael, and Don Gottfredson. 1980. Decision Making in Criminal Justice. Cambridge, Mass.: Ballinger.

Gove, Walter, M. Hughes, and M. Geerken. 1985. "Are Uniform Crime Reports a Valid Indicator of the Index Crimes? An Affirmative Answer with Minor Qualifications." Criminology 23:451-502.

Greenberg, Stephanie, W. Rohe, and J. Williams. 1985. Informal Citizen Action and Crime Prevention at the Neighborhood Level: Synthesis and Assessment of the Research. National Institute of Justice. Washington, D.C.: Government Printing Office.

Guest, Avery. 1984. "The City." Pp. 277-322 in Sociological Human Ecology: Contemporary Issues and Applications, edited by M. Micklin and H. Choldin. Boulder, Colo.: Westview.

Hargens, Lowell. 1986. "Estimating Multiequation Models with Correlated Disturbances." In Common Problems in Social Research, edited by J. Scott Long. Beverly Hills, Calif.: Sage (in press).

Harries, Keith. 1980. Crime and the Environment. Springfield, Ill.: Thomas.

Hindelang, Michael. 1978. "Race and Involvement in Common-Law Personal Crimes." American Sociological Review 43:93-109.

Hindelang, Michael, Travis Hirschi, and Joseph Weis. 1981. Measuring Delinquency. Beverly Hills, Calif.: Sage.

Hogan, Dennis, and Evelyn Kitagawa. 1985. "The Impact of Social Status, Family Structure, and Neighborhood on the Fertility of Black Adolescents." American Journal of Sociology 90:825-55.

Honig, Marjorie. 1974. "AFDC Income, Recipient Rates, and Family Dissolution." Journal of Human Resources 9:303-22.

Janowitz, Morris. 1975. "Sociological Theory and Social Control." American Journal of Sociology 81:82-108.

Kasarda, John. 1983. "Caught in the Web of Change." Society 21:41-47. 1985. "Urban Change and Minority Opportunities." In The New Urban Reality, edited by P. Peterson. Washington, D.C.: Brookings Institution. 
Kellam, S., R. Adams, C. Brown, and M. Ensminger. 1982. "The Long-Term Evolution of the Family Structure of Teenage and Older Mothers." Journal of Marriage and the Family 44:539-54.

Kennedy, Peter. 1979. A Guide to Econometrics. Cambridge, Mass.: MIT Press.

Kmenta, Jan, and R. Gilbert. 1971. "Estimation of Seemingly Unrelated Regressions with Autoregressive Disturbances." Journal of the American Statistical Association 65:186-97.

Kornhauser, Ruth. 1978. Social Sources of Delinquency. Chicago: University of Chicago Press.

Lane, Roger. 1986. Roots of Violence in Black Philadelphia: 1860-1900. Cambridge, Mass.: Harvard University Press.

Liebow, Elliott. 1967. Tally's Corner. Boston: Little, Brown.

Liska, A., M. Chamlin, and M. Reed. 1985. "Testing the Economic Production and Conflict Models of Crime Control." Social Forces 64:119-38.

Loeber, R., and M. Stouthamer-Loeber. 1986. "Family Factors as Correlates and Predictors of Juvenile Conduct Problems and Delinquency." Pp. 29-149 in Crime and Justice, vol. 7. Edited by M. Tonry and N. Morris. Chicago: University of Chicago Press.

Loftin, Colin, and Sally Ward. 1983. "A Spatial Autocorrelation Model of the Effects of Population Density on Fertility." American Sociological Review 48:121-28.

Mayhew, Bruce, and Roger Levinger. 1976. "Size and the Density of Interaction in Human Aggregates." American Journal of Sociology 82:86-110.

Messner, Steven. 1982. "Inequality and the Urban Homicide Rate." Criminology 20:103-14.

1983. "Regional and Racial Effects on the Urban Homicide Rate: The Subculture of Violence Revisited." American Journal of Sociology 88:997-1007.

Messner, Steven, and Scott South. 1986. "Estimating Race-specific Offending Rates: An Intercity Comparison of Arrest Data and Victim Reports." Unpublished manuscript, Department of Sociology, State University of New York at Albany.

Moynihan, Daniel P. 1965. The Negro Family: The Case for National Action. Washington, D.C.: Office of Planning and Research, Department of Labor.

Murray, Charles. 1984. Losing Ground: American Social Policy, 1950-1980. New York: Basic.

Orsagh, Thomas. 1980. "Unemployment and Crime." Journal of Criminal Law and Criminology 71:181-83.

Pyle, G. 1974. The Spatial Dynamics of Crime. Chicago: University of Chicago, Department of Geography.

Rainwater, Lee. 1966. "Crucible of Identity: The Negro Lower-Class Family." Daedalus 95:172-216. 1970. Behind Ghetto Walls: Black Families in a Federal Slum. Chicago: Aldine.

1985. "Comments on Papers by Bane and Wilson-Neckerman." Paper presented at conference "Poverty and Policy: Retrospect and Prospects," Williamsburg, Va.

Ross, Heather, and Isabel Sawhill. 1975. Time of Transition: The Growth of Families Headed by Women. Washington, D.C.: Urban Institute.

Sampson, Robert J. 1983. "Structural Density and Criminal Victimization." Criminology 21:276-93.

1985a. "Neighborhood and Crime: The Structural Determinants of Personal Victimization." Journal of Research in Crime and Delinquency 22:7-40.

1985b. "Structural Sources of Variation in Age-Race and Crime-Specific Rates of Offending in Major U.S. Cities." Criminology 23:401-27.

1986a. "Neighborhood Family Structure and the Risk of Criminal Victimization." Pp. 25-46 in The Social Ecology of Crime, edited by J. Byrne and R. Sampson. New York: Springer-Verlag. 
1986b. "Crime in Cities: The Effects of Formal and Informal Social Control." Pp. 271-311 in Communities and Crime, special issue of Crime and Justice, vol. 8. Edited by Albert J. Reiss, Jr., and Michael Tonry. Chicago: University of Chicago Press.

1986c. "Effects of Socioeconomic Context on Official Reaction to Juvenile Delinquency." American Sociological Review 51:876-85.

Sherman, Lawrence, and Barry Glick. 1984. "The Quality of Police Arrest Statistics." Washington, D.C.: Police Foundation.

Skogan, Wesley. 1986. "Fear of Crime and Neighborhood Change." Pp. 203-29 in Communities and Crime, special issue of Crime and Justice, vol. 8. Edited by Albert J. Reiss, Jr., and Michael Tonry. Chicago: University of Chicago Press.

Sørensen, A., K. Tauber, and L. Hollingsworth, Jr. 1975. "Indexes of Residential Segregation for 109 cities in the U.S., 1940-1970." Sociological Focus 8:125-42.

Stack, Carol. 1974. All Our Kin: Strategies for Survival in a Black Community. New York: Harper \& Row.

Sullivan, Mercer. 1983. "Youth Crime: New York's Two Varieties." New York Affairs 8:31-48.

U.S. Bureau of Census. 1982. Census of the Population, 1980: General Social and Economic Characteristics. Washington, D.C.: Government Printing Office.

U.S. Department of Justice, Federal Bureau of Investigation. 1981. Uniform Crime Reports for the United States, 1980. Washington, D.C.: Government Printing Office.

Wilkinson, Karen. 1980. "The Broken Home and Delinquency." Pp. 21-42 in Understanding Crime, edited by T. Hirschi and M. Gottfredson. Beverly Hills, Calif.: Sage.

Wilson, James Q., and Richard Herrnstein. 1985. Crime and Human Nature. New York: Simon \& Schuster.

Wilson, William Julius. 1978. The Declining Significance of Race: Blacks and Changing American Institutions. Chicago: University of Chicago Press.

1981. "The Black Community in the 1980s: Questions of Race, Class, and Public Policy." Annals of the American Academy of Political and Social Science 454:26-41.

1984. "The Urban Underclass." Pp. 75-117 in Minority Report, edited by L. Dunbar. New York: Pantheon.

Wilson, William Julius, and Robert Aponte. 1985. "Urban Poverty." Annual Review of Sociology 11:231-58.

Wilson, William Julius, and Kathryn Neckerman. 1985. "Poverty and Family Structure: The Widening Gap Between Evidence and Public Policy Issues." Paper presented at the conference "Poverty and Policy: Retrospect and Prospects," Williamsburg, Va. (In Antipoverty Policies: What Works and What Doesn't, edited by S. Danziger and D. Weinberg. Cambridge, Mass.: Harvard University Press [in press]).

Wolfgang, Marvin, and Franco Ferracuti. 1967. The Subculture of Violence. London: Tavistock.

Zimring, Franklin. 1981. "Kids, Groups, and Crime: Some Implications of a Well Known Secret." Journal of Criminal Law and Criminology 72:867-85. 